\title{
MENINGKATKAN SIKAP ESTETIS ANAK MELALUI KEGIATAN MELUKIS DENGAN TEKNIK AIRBRUSH DI KB-TK LABSCHOOL JAKARTA
}

\section{Heri Hidayat, Putri Zakiyyah F, Shifa Maulidya H, Nabiela Bada Nafisah}

Fakultas Tarbiyah dan Keguruan UIN Sunan Gunung Djati Bandung E-mail: put3zakiyah@gmail.com

\begin{abstract}
This study aims to determine whether painting activities using the airbrush technique can improve aesthetic taste in early childhood. This research method is to use a qualitative approach and the technique used in this research is literature study. Sources of data from this literature study are none other than journals and the internet related to the issues that have been selected. The results showed that painting using the airbrush technique could improve aesthetic attitudes in children. This is because the airbrush technique is a learning technique in kindergarten that has an aspect of playing while learning.
\end{abstract}

Keywords: Airbrush, Aesthetic Attitude, Childhood Education Early 


\begin{abstract}
Abstrak
Penelitian ini bertujuan untuk mengetahui ada tidaknya peningkatan rasa estetis pada anak usia dini melalui kegiatan melukis dengan teknik airbrush. Pendekatan penelitian kualitatif dan teknik studi kepustakaan digunakan untuk menggali data. Sumber data berasal dari jurnal dan internet yang berhubungan dengan masalah yang telah dipilih. Hasil penelitian menunjukkan bahwa melukis dengan teknik airbrush dapat meningkatkan sikap estetis pada anak. Hal ini dikarenakan teknik airbrush merupakan teknik pembelajaran di Taman kanak-kanak yang memiliki aspek bermain sambil belajar.
\end{abstract}

Kata Kunci: Airbrush, Sikap Estetis, Pendidikan Anak Usia Dini

\title{
Pendahuluan
}

Anak usia dini dalam UU Sisdiknas difenisikan sebagai anak dengan rentang usia 0-6 tahun. Anak usi dini juga disebut dengan anak prasekolah yang menurut Biecheler dan Snowman dalam Soemiarti Patmonodewo adalah anak dengan rentang usia 3-6 tahun. The National Association for The Eduction Of Young Children (NAEYC), dan para ahli di bidangnya memberikan batasan untuk anak usia dini, yaitu: "Early childhood" atau anak masa awal adalah anak usia 0-8 tahun. Beberapa orang menyebut masa ini sebagai golden age karena pertumbuhan dan perkembangan anak sangat pesat dan tidak dapat diulang kembali. (John, n.d.)

Pengertian estetis adalah nilai keindahan yang terdapat dalam sebuah karya atau objek seni dan juga bersangkutan dengan keindahan, baik keindahan alam, seni, atau sastra. Estetis 
secara singkat (di dalam KBBI) diartikan sebagai keindahan, penilaian terhadap keindahan atau menyangkut apresiasi keindahan baik itu alam, seni atau pun sastra. Terdapat beberapa kegiatan yang dapat meningkatkan sikap estetik anak hal tersebut, diantaranya seperti melipat kertas warna, meniru suatu pola, melukis teknik airbrush, membuat bentuk dari plastisin, melukis teknik finger painting, cooking class, mewarnai teknik gradasi, kolase, mozaik, dan lain sebagainya.

Teknik Airbrush merupakan salah satu teknik yang mudah untuk diaplikasikan dalam sebuah seni lukis. Air brush sama dengan teknik mencetak bayangan. Alat atau media yang digunakan dalam kegiatan ini adalah media yang ada disekitar kita, seperti sikat gigi, sisir, spayer, dan penyaringan teh (Mariyanti, Suara, \& Sujana, 2014). Kegiatan melukis dengan teknik airbrush merupakan kegiatan yang akan disukai anak dan mudah untuk dilakukan, selain itu alat atau media yang digunakan juga sangat sederhana. Oleh karena itu penulis memilih judul "Meningkatkan Sikap Estetis Anak melalui Kegiatan Melukis dengan Teknik Airbrush di KB-TK Labschool Jakarta"

\section{Metode Penelitian}

Pendekatan penelitian yang digunakan adalah pendekatan kualitatif untuk mendapatkan data primer. Pendekatan ini untuk mendeskripsikan dan menganalisis fenomena, peristiwa, aktivitas sosial, sikap, kepercayaan, presepsi, dan orang baik individual maupun kelompok secara apa adanya (Sukmadinata, 2009). Studi pustaka dilakukan dengan browsing di internet dan jurnal untuk mendapatkan data sekunder dengan mengumpulkan sejumlah buku-buku, majalah, liflet, literatur, catatan-catatan, dan laporanlaporan yang berkaitan dengan Upaya Meningkatkan Sikap Estetis 
Pada Anak Usia Dini Melalui Kegiatan Melukis Dengan Teknik Airbrush Di Kb-Tk Labschool Jakarta.

\section{Hasil dan Pembahasan}

A. Pengertian Estetetika dan Sikap Estetis

Estetika berasal dari Yunani aesthetica yang berarti hal-hal yang dapat diserap oleh panca indera dan aesthesis yang berarti penyerapan indera.

Unsur-unsur estetika yang berkarakter menentukan ekspresi bentuk. Unsur-unsur tersebut yaitu:

1. Garis. Garis tercipta dari sebuah titik yang tidak berdimensi tetapi ketika titik tersebut bergerak satu sama lain, maka akan menjadi sebuah garis yang berdimensi.

2. Bentuk. Bentuk adalah sebuah garis yang menutupi suatu area, mengacu kepada kontur garis, garis paling luar sebuah bidang, atau batas dari massa atau volume tiga dimensi.

3. Tekstur. Tektur adalah suatu bentuk permukaan yang dapat dirasa melalui indera peraba.

4. Warna. Warna adalah suatu elemen desain yang paling ekspresif karena kualitasnya menyebabkan seseorang emosional. (Rosadi, 2013)

Estetika adalah suatu ilmu yang mempelajari tentang keindahan dari segi apapun dan aspek apapun. Sikap estetis terdiri dari dua kata yang memiliki kesatuan. Sikap diartikan sebagai perilaku yang diharapkan terbangun pada anak sesuai dengan kompetensi sikap spiritual dan kompetensi sikap sosial yang tercantum dalam kurikulum 2013 PAUD. KBBI mengartikan estetis sebagai sesuau hal yang berkaitan 
dengan keindahan atau menyangkut apresiasi keindahan (alam, seni dan sastra) dan mempunyai penilaian terhadap keindahan.

Berdasarkan pengertian dari sikap dan estetis yang telah dijelaskan di atas, maka dapat disimpulkan bahwa sikap estetis adalah perilaku yang diharapkan terbangun terkait keindahan terhadap suatu objek yang berasal dari alam, atau objek tertentu.

B. Teknik Airbrush

Teknik airbrush merupakan suatu teknik menggambar dan melukis dengan menyikatkan sikat gigi yang sudah dicelupkan pewarna, pada sisir untuk menghasilkan bentuk gambar bayangan. Teknik ini sama halnya dengan teknik mencetak bayangan. Teknik airbrush memanfaatkan tetestetes atau cipratan-cipratan kecil yang dihasilkan oleh sikat gigi dan sisir tersebut (Naidia, Yuhasriati, \& Rosmiati, 2020)

Media yang digunakan dalam teknik ini sederhana. Salah satu media yang digunakan dalam teknik ini adalah sisir, sikat gigi, daun, kertas putih kosong, cat dan air. Teknik ini merupakan pembelajaran yang mengandung aspek bermain sambil belajar sebagai salah satu teknik pembelajaran di TK (Mariyanti, Suara, \& Sujana, 2014).

C. Meningkatkan Sikap Estetis melalui Keiatan Melukis dengan Teknik Airbrush di KB-TK Labschool Jakarta

Berdasarkan hasil pengamatan dari kegiatan melukis dengan teknik airbrush di KB-TK Labschool Jakarta melalui media internet yaitu Youtube, dapat disimpulkan sebagai berikut:

Pengembangan estetika dengan metode melukis huruf hijaiyah dengan teknik cipratan dan percikan atau yang 
lebih dikenal dengan airbrush, alat dan bahan yang diperlukan yaitu: kertas polos atau kertas karton, sikat gigi yang tidak terpakai, sisir, cat air atau pewarna lain, serta bentuk huruf hijaiyah dan hiasan lainnya.

Cara mengaplikasikannya yaitu: taruh terlebih dahulu huruf hijaiyahnya di kertas polos atau kertas karton, lalu celupkan sikat gigi pada cat air atau pewarna, setelah itu gosokan sikat gigi yang sudah diberikan warna pada sisir lalu ratakan seluruh warna pada huruf hijaiyah tersebut, jika sudah selesai buka terlebih dahulu huruf hijaiyah tersebut setelah itu akan terlihat hasil nya yang sangat indah.

Dengan menggunakan teknik airbrush atau cipratan seperti ini anak akan banyak sekali mengeksplor berbagai macam tentang warna yang bisa digradasikan pada objek yang akan di cipratkan dan juga dapat mengeksplor semua hal tentang cara melukis dengan berbagai macam teknik.

\section{Kesimpulan}

Melukis dengan menggunakan teknik airbrush dapat meningkatkan sikap estetis pada anak. Hal ini dikarenakan teknik airbrush merupakan teknik pembelajaran di TK yang memiliki aspek bermain sambil belajar, teknik ini juga menggunakan media sederhana yang mudah kita dapatkan di sekitar kita. Selain itu, seperti yang sudah dijelaskan sebelumnya teknik ini bermanfaat untuk anak karena teknin ini banyak sekali mengeksplor berbagai macam tentang warna yang bisa digradasikan pada objek yang akan di cipratkan dan juga dapat mengeksplor semua hal tentang cara melukis dengan berbagai macam teknik. 


\section{UCAPAN TERIMA KASIH}

Penulis ingin mengucapkan rasa terima kasih kepada semua pihak yang telah membantu dan mendukung penulis dalam membuat jurnal ini, terutama kepada KB-TK Labschool Jakarta yang telah membuat video melukis dengan teknik airbrush ini, sehingga bisa dijadikan sebagai bahan untuk diteliti. Dan juga kepada bapak Dr. Heri Hidayat, S.Sn., M.Pd, I. selaku guru pengampu dalam mata kuliah pengembangan estetika sehingga jurnal ini dapat diselesaikan.

\section{Daftar Pustaka}

John, D. (n.d.). Pengertian Anak Usia Dini Menurut Beberapa Cendekiawan. Retrieved from Silabus.Web.id: https://www.silabus.web.id/anak-usia-dini/

Mariyanti, N. P., Suara, I. M., \& Sujana, I. W. (2014). PENERAPAN METODE PEMBERIAN TUGAS MELALUI KEGIATAN AIRBRUSH UNTUK MENINGKATKAN PERKEMBANGAN MOTORIK HALUS ANAK TK KELOMPOK B. e-Journal PG-PAUD Universitas Pendidikan Ganesha, 4-5.

Naidia, R., Yuhasriati, \& Rosmiati. (2020). Perkembangan Motorik Halus Anak Melalui Kegiatan Airbrush pada kelas B di TK Ilagang Kabupaten Bener Meriah. Jurnal I/miah Mahasiswa Pendidikan Guru Anak Usia Dini, 4.

Ningsih, L. (2018). Upaya Meningkatkan Sikap Estetis Pada Anak Melalui Kegiatan Menggambar di RA Islamiyah Tanjung Morawa. Skripsi. Medan. Universitas Muhammadiyah Sumatera Utara.

Rosadi, J. (2013). Kajian Estetika Thomas Aquinas Pada Interior Kayu Aga House di Canggu Bali. Jurnal Intra, 1-2.

https://www.youtube.com/watch?v=xHX2PqaZOr4\&t=100s 